\title{
RPL29 wt Allele
}

National Cancer Institute

\section{Source}

National Cancer Institute. RPL29 wt Allele. NCI Thesaurus. Code C53158.

Human RPL29 wild-type allele is located within 3p21.3-p21.2 and is approximately $2 \mathrm{~kb}$ in length. This allele, which encodes 605 ribosomal protein $L 29$, is involved in the progression of protein synthesis. This gene may play a role in both type I diabetes caused by autoimmunity and the progression of colon cancer. 